\title{
Person Earth
}

\section{GEORGE ABBE}

I entered a white room flawless with sterile glittering light. Scientists bent to tear the skin from animals held taut, or burned them with radiation, or crushed their limbs with weights. Cosmetics were tried on the eyelids of rabbits gripped by the neck; their eyeballs glazed to blindness; most of them died in the test.

I had willed an astral journey to the laboratories of horror, where man inflicts on the helpless the pangs of his own dark sorrows, the disease of his civilized emptiness, the shock of his fear. His gadgets, his physical safety, his futile self-amusement shone in the cold technician's eye, the pitiless beauty of power untouchable, computer precision that haloed the head of the whiteclad instrument wielder the public extolled as God, since their one overwhelming aim was to.. put off death, no matter what value or virtue their life might attest.

The drug administration dogs cried in their cramped cages; poisoned, convulsed, they arched their backs, they lingered for days; retching, hemorrhaging, they dropped-and rose to strive again.

I came with psychic power; on the wave of a dream I entered. On falling asleep, I had willed a search for the lost and spent, Earth's weak and suffering creatures, "the least of these, my brethren," Christ had exhorted us to discover and lift with love.

Often I had reflected:

"If only the lab animal could save himself by suicide, could thwart and madden his captors by quick self-extermination."

Often I'd burned to intercede, to save him from pain; and now in my dream, my astral visit, I came to break through time, to attain. When the scientists had left their work, I cried:

"Friends, blest comrades of that innocent good, purer than men, gentle and trustworthy, I expiate our mortal curse. I will, by the force of my love and compassion, your release."

So, some who twisted in torment I touched; they let go and died; and some halfway across death I eased or pushed to their prize. I broke the silver cords of many who could not make the effort themselves; I drew them, I gave them shining escape.

Dazzled, exultant to save, I worked till the last was free, and drained of strength, turned to go, when a voice cried suddenly from beyond the wall. I burst in a door, stumbled into a room of caged men--men in vises, or poisoned by drugs, and doomed to die, by water, fire, implanted cancer, endless experiments--all that animals had been forced to suffer for centuries.

And high over antiseptic tables, instruments, walls, a huge sign hung: fail."

"Be proud of Technasia. Science cannot

I questioned a dying man, cut open, spasming; he raised his head:

"Political prisoners, hippies, drug addicts, the sick and unwanted--a logical step--and, like weaker creatures, we never consented."

His voice ceased, the scene paled. I floated, journeyed through the deep sky.

I settled back into my body, in my room --woke to a normal Unarian day.

Where the two nations' boundary ran, bisecting the mountain, the woods began. In Unaria's forests, where still the wild rock

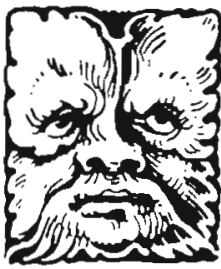

State University of New York, Plattsburgh. 
cascades fell, the air stretched clean and steep like an open street to God's citadel, the ancient sun throbbing its secret occult love for Jnaria, the last land where Nature, saved, still lived with men.

And on that border's other side, Technasia, treeless, sloped to valleys bright and solid with towers, with endless walls and pavement floors crushing off the Earth's last seed, its last cut rocks. No grass grew. The plants that fought for light died in the festering air, smog, rock music, the roar of savage movement and machines that stifled the blood of humans and the veins of traffic pulsing far as eye could see--all drugged and struggling, straining to die.

From valley to hill to ocean there hung steel vegetation, the deathly song of jet plane, missiles, transport truck, demolition derby, war-game guns; while under Unaria's cliffs the deer browsed, and above, the eagle soared.

At this division, this mountain border, the world court held debate. Technasia proclaimed her right to share Unaria's resources; her own were gone.

The strong-browed, sharp-chinned Lanac, Technasia's statesman, rose to speak, and at his back, poised silently for miles, the finest of the country's fighters stood, weapons at alert, eager to invade. Unaria had no army, no men trained for force, save local guards.

"We are progress!" he cried. "We are success itself. And yet we need material treasure to continue and extend man's lifetime and his travels farther through stellar space. If Urania refuses to give, we'll simply invade and coerce."

Rabor, Urania's President, best known for psychic power, communion with beauty in every creature and thing, sprang to his feet.

"You demand that men of vision and compassion who built the balanced nation of Urania now yield her glory to your warped cupidity? We who learned discipline of spirit, who found the secret of speech with all wild life and with inanimate things, who live happy and godlike because we take no life for meat and have taught all to flourish without doing hurt--our total community thrives on
Negavit, a non-living food; we turned our resources, experiments into that one merciful search, while you, Technasia, wasted your creatures, your land, your days only for pleasure and power, physical safety and ease.

"You murder and pollute; we heal and lift. And now you would pollute and kill in Unaria whatever breathes and grows."

I stood beside Rabor; I saw the lines of Technasia's fighters, armed, stretching for miles; beyond them, through the dying cities the bright leprous yellow of befouled rivers ran fishless, birdless, reeking. And from one tower hung a figure naked, cursed by all who passed--his body lasted to a wheel, twisted, slashed--our Uianian prophet, Tibul, flame-eyed, noble, rash, who had prophesied Technasia's doom.

"The earth is a person!" he had cried. "She hoards her wounds; she will take revenge; she will turn and strike you with savage disaster--apocalyptic, complete. But Unaria will be spared; the earth has a mind, a keen spirit; she knows her friends; her acts are based on love and the laws of natural rightness, compassion."

Lanac's face, gray as the pavement of his sapless world, flushed with ire.

"Look overhead!" He pointed. Airplanes rolled and glittered in stark maneuvers, reeled and spun in fury. "They watch the earth. In minutes, they can blast, geyser, bury each city, every sentient thing. Such power is needed to advance mankind to resplendent destiny, our control of genes, the very removing of chance from life itself, to make whatever categories and traits we may prescribe.

"And you--despicable, tiny nation boring the rest of us with your Nature cant, your sentimental bilge about the balance of life-because you haven't the guts to indulge in the sensuous and free-you with your moderation, your sick spirituality and sentimental pity-do you think we'll break our skull with headache because you corner the pills?"

Lanac shrugged and laughed--a bitter, ugly laugh.

"Like hell! We'll spill your sap to the last drop first--your animals, men, birds, 


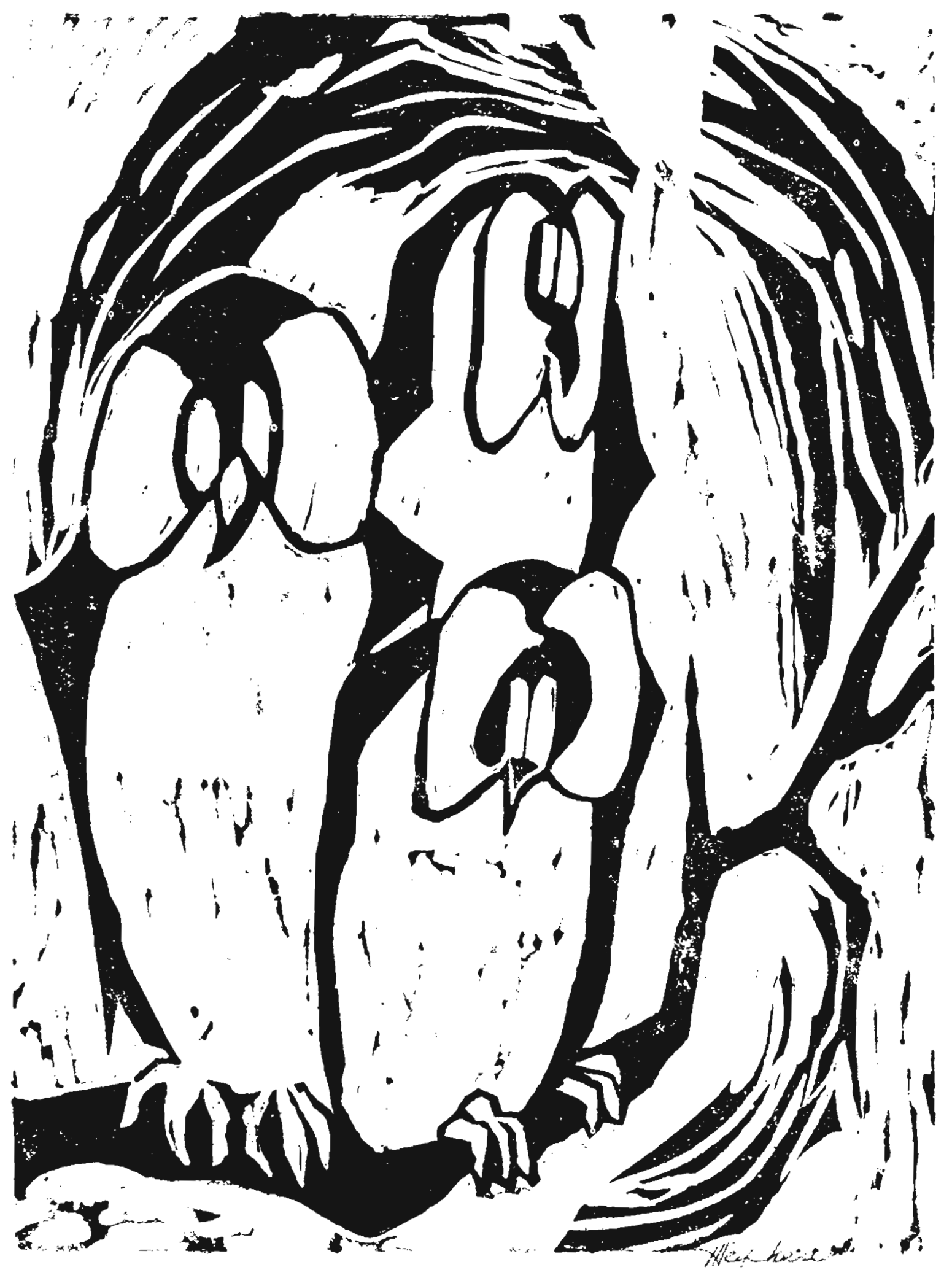


plants, insects--everything your lunacy reveres we'll curl in a neat, singed, blackened ash, and blow it to the night wind's grave."

"You talk the hectic arrogance of fear," I said. "You strain too hard at toughness to be brave. Iook there upon the tower--Tibul the prophet moves. He is not dead. Now wait, now watch."

I spoke, and all along Unaria's boundary mountains the rock shuddered and groaned, and the trees lurched. A strange aura burned-colors so awesome one sensed a transcendent Person breathing and turned his gaze aside.

"See! Tibul stirs!" Rabor exclaimed. "The Earth's spirit rises to defend!"

"Watch now!" I cried. "A flame threadlike and strong is spun from our peaks and crosses over to wind that naked suffering prophet-body in beautifully flashing skin-cloth of all God and Nature, the flawless protection of mercy."

Lanac swung about to stare. The prophet lashed to his steel-wheel rack, smiled now; an emanation, a vibrant hue, arching and sliding like joyous porpoises weaving enraptured water in texture of flying, flickered and spumed from peak to broken limbs and sprung bones.

"Degeneracy has built your cities, Lanac!" I cried. "No sin surpasses the apathy of the corrupt, the clever power."

And Rabor added:

"There is a reckoning. The soul's core closed in the Earth's entity, the long-maturing self whose body we plundered--that retributive spirit rises to engulf the pillagers, the scientific ruthless and exact, who tore its soil, crossed space, wasted infinite living for dead fact."

There was a silence, and out of it suddenly, slashing like shark under foam--voices --Technasia's army--a thrusting sawtooth sound--a stroke of pitiless ugliness repeated from throats of all those tight-ranked and stretching on that razor-straight boundary, one side wooded, the other dead, bare, treeless--a sound from thousands of throats in mechanical chant:

"God is Dead! Nature is Dead! They are myths--the reek of the past!"

Over and over the words struck, tearing, ripping. I felt the hate, the psychotic resolve. Then Rabor turned, pointed to a dazzling spit of flowering meadow shot between coves of spruce and oak. A waman ran there--lithe, radiant, eyes crying the boundless summons of realms etheric; her breasts and thighs were milky, breathlessly pure.

The pheasant she followed stopped; she bent to converse; you could feel the air kindle and ripple between; her lips moved; the pheasant's colors tingled, his eyes were speech; an aura about both forms made bolder and clearer the bulk of mountains, flowers, flying birds.

"What do they say?" Lanac taunted.

"They talk about children, which ones have created the art of the spirit lately, beast or human," Rabor pealed his retort like a mystic bell, "whose paintings, poems, music swarm our hills clairvoyant-telepathic-visionary alive, a deeper spell, esthetic impact more compelling because it needs no screen, no page, no canvas, no instrument save love's soul and brain--communion of Christ's will."

Lanac snorted contempt.

"And look!" I cried.

A fox pursuing a rabbit caught up; they stopped; they spoke amiably, with wit--no blood, no predatory shock of violence. Then both ate the white Negavit sparkling in the grass. A wolf loped beside a deer; they loitered, pressed mouths to Negavit; they laughed their friendship silently, reverberant with ease and affection.

"And as Isaiah predicted," I said, "the lion and the lamb actually lie down together."

And there on the meadow people came to eat and rewardingly talk with creatures, plants, all that is, for all is animate, suffused with Christ. And I recalled those first racking years of doubt, trial, seeking the holy equality, the just and perfect order in which none need eat other life in order to live. If I prayed for the rabbit, and the white shield of my prayer preserved him from the fox, then the fox did not eat; if I 
prayed for the hawk, then the lark I loved as much must die to fulfill my prayer.

And the pheasant's heart must cease for the owl to eat, and the fish suffer death to save the mink.

So how could I pray at all, how love, show mercy, perceptively think, if all gain by the hungry meant torture, or death to a creature equally good? And so all our will, our science were poured into making the flawless food derived from no substance that ever had lived, no mineral, vegetable, hint of blood or breathing or atom or element--a material inspired by the living Christ himself to deliver us at last from inflicting harm to aoquire sustenance, because we wholly and selflessly formed our prayers of the single devout reckless desire to outlaw torment or murder for any cause. And so we achieved that Utopian kingdom of brothers, which all religions and prophets have preached.

As I stood there recalling, suddenly Lanac's voice rang:

\section{"Conquer!"}

The endless line of fighters pressed forward with a cry. But instantly, before them, the Earth gaped, a straight rift deepened, groaned. The mountains shook. Technasia's cities quivered, her pavements broke, and into darkness the swarming engines fell, the people sank; and a voice, marvelously god-like, strong, rolled like a billow in air:

"The Earth avenges; no pity is lost; Christ, we have you to thank!"

It was Tibul. The metal wheel of his agony crackled with violet fire--violet, the hue of angel healing; and Tibul's face exhaled a light like breathing, a cleansed flame that ravaged and appalled, exploding in my blood the rapture of revelation, and praise, a joy pristine, a livingness too awesame for the tongue.

The fissure spread; the fighters, panicking, recoiled, screaming; steam rose; a leprous ugly blaze shot through.

"This is the savage salvation of that spirit that has nourished us!" Rabor cried. "--which we betrayed--that dreaming beauty under rock, strict truth and judgment Christ ordained, abused and wounded, apocalyptic finally, gushing its pain for our proper penance--the restoration of Nature through man's extinction--all save the meek and merciful, those few of Unaria's family, doers and givers, who made all else as sacred as their humanity."

The woman in the meadow raised her arms. Animals, plants, trees, soil, rocks, flickered with a wild and gentle radiance; a power like a voice-sun-touch from cosmic centers, it sprang across Unaria's boundary, the spreading chasm where men downflung clashed arms, and, tumbling, were lost; it struck the Machine Age wheel, the wire-bound wrists of Unaria's prophet; the wire caught fire and fell.

Tibul slid down; he stood whole, transfigured, on the reeling street. His hand stretched out to us, and ours to him; and as he moved to rejoin Unaria, our mingled speech was Nature and Love; and what our bodies and spirits spoke rose like the resonant cry of Christ himself, who out of the Earth's convulsion might arise soon--soon, perhaps--to blend all Nature's creatures and his fire in the new and purified--a communal sacred to endure--simple, pastoral again, restricted by law to small population, to insure reverie, spirit growth, the full and generous heart-and, out of openness and courage, prayer.

Technasia, crumbling like Pompeii, Rome, Babylon, dissolved before our eyes; the boundary fissure, widening, ran to the sea, the bloody glare of sinking sum; and up that huge crevasse the flood poured, covering airdromes, highways, atomic plants, the frantic swarm of engines, the swollen movement of crowds knotting and lumping beneath the sickly bright haze of their terror, like pus under pressed skin about to burst forth.

The chasm closed slowly; the pavements of the Age of Progress were gone. Behind us the living green slopes rose, Unaria's rocky spires and winds, her birds and clouds, the trees' wood spun from Person Earth, ring on ring like cycles of praise and beauty expanding in epic song, refreshment drawn from the Spirit's pristine cap and the marrow of Mind. 